\title{
A case of B.1.1.7 SARS-CoV-2 UK strain with an atypical radiological presentation
}

\author{
Emrah Dogan, Utku Tapan, Özge Oral Tapan, Fatih Alaşan, Sabri Serhan Olcay, Tuğba Çınar Olcay \\ Department of Radiology, Faculty of Medicine, Mugla Sitki Koçman University, Mugla, Turkey
}

\begin{abstract}
The new UK strain was first described in December 2020. It was seen for the first time in Turkey in February 2021. It is not yet known whether the new strain has different CT patterns compared to the classical type. We present a 68 -years-old male patient with an atypical CT presentation in which GGOs are gathered around the areas of paraseptal emphysema accompanied by $\mathrm{CT}$ and clinical
\end{abstract}

Correspondence: Emrah Doğan, Department of Radiology, Faculty of Medicine, Muğla Sıtkı Koçman University, 228 sok. Obam sitesi No:15 Kötekli/Menteşe, Mugla, Turkey.

Tel. +90.5066619794 - Fax: +90. 2522123599.

E-mail: emrahdogan@mu.edu.tr

Key words: COVID-19; UK strain; B.1.1.7; computed tomography.

Contributions: All the authors contributed to paper preparation. All of them read and accepted the last version of the manuscript. They

accepted to be responsible for all aspects of the paper.

Conflict of interest: No conflict of interest between authors

Availability of data and materials: All data used in the paper are available in the hospital data system.

Ethics approval and consent to participate: No ethical committee approval was required for this case report by the department because this the article does not contain any studies with human participants or animals. Informed consent was signed by the patient.

Consent for publication: The patient gave consent for the publication of this case report and any accompanying image

Funding: The author has no financial interest to declare in relation to content of this article.

Acknowledgement: Endless thanks to Dr Marwa Mouline Doğan for her help in preparing the manuscript.

Received for publication: 10 March 2021.

Accepted for publication: 28 April 2021.

${ }^{\circ}$ Copyright: the Author(s), 2021

Licensee PAGEPress, Italy

Monaldi Archives for Chest Disease 2021; 91:1840

doi: 10.4081/monaldi.2021.1840

This article is distributed under the terms of the Creative Commons Attribution Noncommercial License (by-nc 4.0) which permits any noncommercial use, distribution, and reproduction in any medium, provided the original author(s) and source are credited. findings. This involvement is an unexpected pattern because of the atypical distribution of the GGO.

\section{Introduction}

A new, highly contagious respiratory pathogen belonging to the coronavirus (CV) family was first reported in December 2019 in Wuhan, China. This virus is named severe acute respiratory syndrome coronavirus-2 [SARS-coV-2]. WHO officially named this disease COVID-19 [1]. COVID-19 is a disease that may lay to various levels of pneumonia, acute respiratory distress syndrome (ARDS), respiratory failure, pulmonary and systemic thromboembolism, systemic inflammatory response, sepsis and necrotizing encephalopathy [2]. In December 2020, the new UK strain was defined for the first time. The UK strain SARS-coV-2 started to be detected in Turkey in February 2021. In the report published by UK Health Agency Public Health England on December 29, 2020, it was stated that the new variant was not worse than the classical type in terms of hospitalization risk and disease severity [3].

In association with PCR (Polymerase Chain Reaction), thorax CT remains the most important diagnostic method in the primary evaluation and the follow-up of COVID-19 [4]. It shows the progression of the disease, its severity, and the effectiveness of the treatment. Especially in the early phase, when the viral load is low, $\mathrm{CT}$ can be positive [2]. Therefore, CT findings are crucial for the evaluation of disease progression.

CT findings of the classical type COVID-19 are now wellknown and there are many articles on this subject. The existence of the UK strain is quite new. As far as we know, there are not enough articles about the CT findings of this new strain at the time of writing our paper. It is not yet known whether the UK strain shows a different character in CT compared to the classical type. A CT feature that was not encountered in the classical type, was seen in our patient infected with the novel strain. This involvement was not also defined in the literature as a feature of the classical type. We present a 68-years-old male patient with an atypical CT presentation in which GGOs are gathered around the areas of paraseptal emphysema accompanied by CT and clinical findings.

\section{Case Report}

Our patient is a 68 -year-old male physician. The patient's complaint started with subfebrile $\left(38^{\circ} \mathrm{C}\right)$ fever. There was a history of coronary artery disease and hypertension (HT) in the patient's anamnesis. There was no history of smoking. We found the notion of risky family contact. His daughter and son-in-law were already 
PCR positive. The diagnosis of COVID-19 is made on the basis of a positive PCR test. B.1.1.7 SARS-coV-2 UK mutation was observed in the advanced biological analysis. The general condition of the patient was initially good. He was conscious and his vital signs were normal. Oxygen saturation was $98 \%$, respiratory sounds were normal. The patient had been vaccinated with Coronovac (Sinovac Biotech) twice on 14 January and 14 February. Antibody titer was over $1 / 10$. Laboratory findings of our patient during his hospitalization are noted in Table 1.

Favipiravir was indicated for treatment. The initial treatment consisted of $5 \times 2$ tablets of $200 \mathrm{mg}$ for 2 days. The maintenance treatment consisted of 6 tablets $3 \times 2$ per day for 8 days. The patient's fever rose to $39^{\circ} \mathrm{C}$ on the $5^{\text {th }}$ day of treatment, so it was decided to introduce $40 \mathrm{mg}$ of methylprednisolone (Prednol) IV once daily for 5 days. The fever was controlled with $2 * 3$ paracetamol tablets of 500 $\mathrm{mg}$. There was no evidence of bacterial infection documented from urine samples and tracheobronchial secretions. However, superinfection was suspected because of the high febrile level and the appearance of purulent sputum. Thus, empiric antibiotic treatments (ceftriaxone 1 gr 1 x 2 per day and moxifloxacin $400 \mathrm{mg} 1$ x 1 per day) were added to the treatment for a period of 7 days.

The first CT performed on 26 February 2021 did not show any evidence of infection. However, peripheral paraseptal emphysema was detected in the upper lobes. On the second CT scan performed 6 days later, it was seen that the GGOs were gathered around the areas of paraseptal emphysema. The distribution of GGOs was atypically in the upper lobes and anterior zone (Figure $1 \mathrm{a}, \mathrm{b}$ ). Besides, there were small nodular rounded GGOs located in the lower lobe scattered in the parenchyma (Figure $1 \mathrm{c}, \mathrm{d}$ ).

\section{Discussion}

The geneticist Nick Loman from the University of Birmingham first described the existence of a different strain in the city of Kent in December 2020. This type named the SARS-CoV-2 UK B.1.1.7 strain. Although this variant does not have a difference in its virulence and disease-causing ability, it is stated that the spread rate of the virus is higher than the classical type. Also, it is not expected to be resistant to vaccines [5].

The classical radiological features are clear. The diagnostic profile accepted nowadays in CT is a pure GGO or GGO pattern associated with consolidations. The involvement is generally basal, posterior, peripheral and bilateral [4]. In all of the classifications, if the involvement is dominant in the upper lobe, the patient is then categorized in the group of indeterminate appearance. This is valid for anterior involvement, too. The involvement around emphysema or bullous areas is not expected as a classical appearance.

Paraseptal emphysema generally associated with smoking, refers to a subtype of pulmonary emphysema which is located in the periphery of the lung and adjacent to the septal lines. The periphery of the upper zones is mostly affected. It is commonly seen in the subpleural area. In our patient, some emphysema areas exceeded $1 \mathrm{~cm}$. Terminologically, air gaps larger than $10 \mathrm{~mm}$ are called bullas. These may or may not have septations [6]. In the present case, GGOs were gathered around the emphysema areas located in the upper lobe. In other words, the virus has preferred areas with relatively high oxygen saturation in the lungs. It is well known that aerobic microorganisms in bacteria group such as nocardia, pseudomonas, Mycobacterium tuberculosis and Bacillus antracis usually involve the upper zones in the lung $[7,8]$. However, viruses are microorganisms with different dynamics compared to bacteria. The interaction between oxygen and viruses has been explored since the beginning of the $20^{\text {th }}$ century. Although the terms aerobic-anaerobic are not used for viruses, the aerophilic properties of some viruses such as influenza are known. let's point that the radiological behaviours of coronaviruses resemble that of influenza. In a study by Morinet et al., it was shown that low oxygen levels negatively affect influenza replication $[9,10]$. It is not known whether the mutation in the new viral strain changed the relationship of the virus with oxygen. However, in our case, the involvement was concentrated in the upper zone and especially around the paraseptal emphysema.

To this day, we know only the short- and medium-term results of COVID-19 involvement. It has been reported that the disease causes cystic changes like pneumatocele [11]. Apart from this, when infection occurs in small calibre $(<5 \mathrm{~mm})$ cystic lesions within GGO areas, it is known as the vacuolar sign [12]. This finding is very common. The reported prevalence of this lesion was between $8.1 \%$ and $54.8 \%$ [13]. However, there is no evidence that it causes emphysema or specifically paraseptal emphysema seen around GGOs like in our case. In addition, no paper showing that the GGO due to COVID-19 is clearly clustering around areas of emphysema has so far been reported. COVID-19 is known to cause fibrosis. It is still uncertain whether emphysema, which is the result of long-term damage, will be among the late post-covid symptoms [14].

\section{Conclusions}

At the time of writing our case report, there is no enough radiological paper concerning the new B.1.1.7 SARS-coV-2 UK strain. In our case, there is GGO involvement in the upper lobe and around the emphysema. This GGO involvement in high oxygenated areas is an unexpected pattern in COVID-19 pneumonia.

Table 1. Laboratory findings.

\begin{tabular}{|c|c|c|c|c|c|c|c|c|c|c|c|}
\hline Day & $\begin{array}{l}\text { White } \\
\text { blood } \\
\text { cells } \\
\left(10^{9}\right)\end{array}$ & $\begin{array}{l}\text { Neutrophile } \\
\text { (mcL) }\end{array}$ & $\begin{array}{l}\text { Lymphocyte } \\
\text { (mcL) }\end{array}$ & $\begin{array}{l}\text { Procalcitonine } \\
\text { (ng/mL) }\end{array}$ & $\begin{array}{l}\text { C-reactive } \\
\text { protein } \\
\text { (mg/L) }\end{array}$ & $\begin{array}{l}\text { Troponine } \\
\text { (ng/mL) }\end{array}$ & $\begin{array}{l}\text { D-dimer } \\
\text { (1/g/L FEU) }\end{array}$ & $\begin{array}{l}\text { Glucose } \\
(\mathrm{mg} / \mathrm{dl})\end{array}$ & $\begin{array}{l}\text { Urea ( } \\
(\mathrm{mg} / \mathrm{dl})\end{array}$ & $\begin{array}{l}\text { Creatinine } \\
(\mathrm{mg} / \mathrm{dl})\end{array}$ & $\begin{array}{l}\text { Ferritin AST ALT } \\
(\mathrm{ml} / \mathrm{ng})(\mathrm{IU} / \mathrm{L})(\mathrm{U} / \mathrm{L})\end{array}$ \\
\hline February $26^{\text {th }}, 2021$ & 8.31 & 6.35 & 1 & & 44 & & 113 & & 20 & 0.92 & \\
\hline February $27^{\text {th }}, 2021$ & 7.59 & 4.94 & 1.39 & 0.088 & & 15 & 140 & 97 & 27 & 0.91 & \\
\hline March $1^{\text {st }}, 2021$ & 5.21 & & 0.95 & 0.088 & 10 & & 171 & & 27.9 & 0.93 & \\
\hline March $3^{\text {rd }}, 2021$ & 4.37 & & 0.75 & 0.082 & 18.81 & & 90 & & 30.2 & 0.87 & 155.7 \\
\hline March $4^{\text {th }}, 2021$ & 6.42 & 5.54 & 0.54 & & 24.28 & & 155 & & 40 & 0.95 & 16 \\
\hline
\end{tabular}




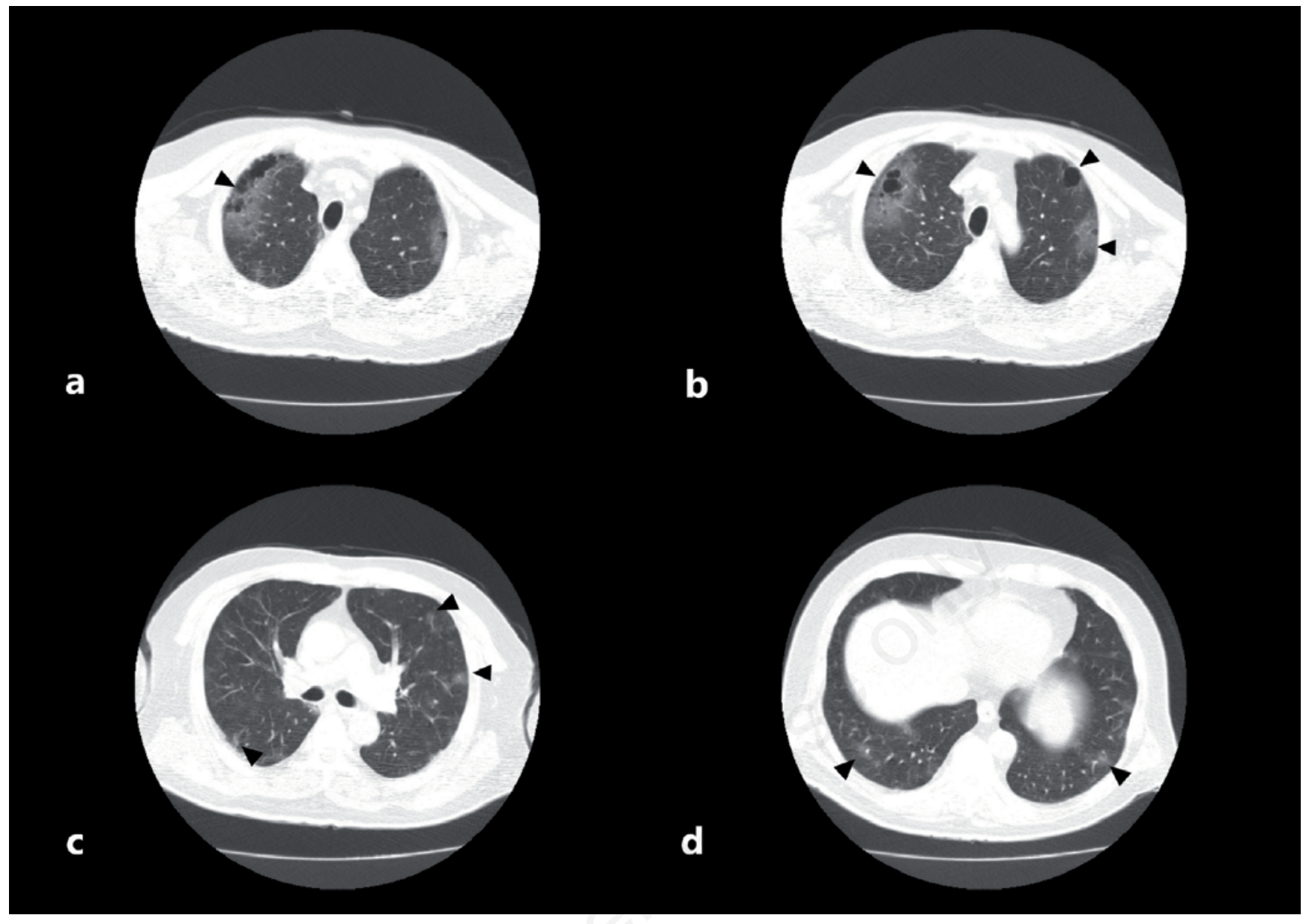

Figure 1. a,b) GGO pattern around paraseptal empysema located in upper and anterior zone around paraseptal empysema. c,d) Scattered rounded GGOs in lower and middle zone of the lung.

\section{References}

Tenda ED, Yulianti M, Asaf MM, et al. The importance of chest CT scan in COVID-19. Acta Med Indones 2020; 52:68-73.

Ufuk F, Savaş R. Chest CT features of the novel coronavirus disease (COVID-19). Turk J Med Sci 2020;50:664-78.

Kirby T. New variant of SARS-CoV-2 in UK causes surge of COVID-19. Lancet Respir Med 2021;9:20-1.

Salehi S, Abedi A, Balakrishnan S, Gholamrezanezhad A. Coronavirus disease 2019 (COVID- 19): A systematic review of imaging findings in 919 patients. AJR Am J Roentgenol 2020;215:1-7.

Kupferschmidt K. Fast-spreading U.K. virus variant raises alarms. Science 2021;371:9-10.

Takahashi M, Fukuoka J, Nitta N, et al. Imaging of pulmonary emphysema: a pictorial review. Int J Chron Obstruct Pulmon Dis 2008;3:193-204.

Garg M, Prabhakar N, Gulati A, et al. Spectrum of imaging find- ings in pulmonary infections. Part 1: Bacterial and viral. Pol J Radiol 2019;84:205-13

Franquet T, Chung JH. Imaging of pulmonary infection. In: Hodler J, Kubik-Huch RA, von Schulthess GK, editors. Diseases of the chest, breast, heart and vessels 2019-2022: Diagnostic and interventional imaging [Internet]. Cham: Springer; 2019. Chapter 7.

Morinet F, Parent M, Bergeron C, et al. Oxygen and viruses: a breathing story. J Gen Virol 2015;96:1979-82.

Koo HJ, Lim S, Choe J, et al. Radiographic and CT features of viral pneumonia. Radiographics 2018;38:719-39.

Hamad AMM, El-Saka HA. Post COVID-19 large pneumatocele: clinical and pathological perspectives. Interact CardioVasc Thor Surg 2021;ivab072.

Zhou S, Wang Y, Zhu T, Xia L. CT Features of coronavirus disease 2019 (COVID-19) pneumonia in 62 patients in Wuhan, China. AJR Am J Roentgenol 2020;214:1287-94.

Ufuk F, Savaș R. Chest CT features of the novel coronavirus disease (COVID-19). Turk J Med Sci 2020;50:664-78.

Han X, Fan Y, Alwalid O, et al. Six-month follow-up chest CT findings after severe COVID- 19 pneumonia. Radiology 2021;299:E177-6. 